\title{
Undernutrition in lepromatous leprosy, Part I. Is it associated with poverty or with disease?
}

\author{
K N RAO, V LAKSHMI* \& K SAHA \\ Department of Immunology, Vallabhbhai Patel Chest Institute, \\ University of Delhi, Delhi-110007; *Department of Dietetics, \\ Medical College, Rohtak-124001, India.
}

Accepted for publication 22 May 1986

\begin{abstract}
Summary Body dimensions (weight, height, and skinfold thickness) were measured of 339 normal subjects and $239 \mathrm{BL}$ and LL patients of both sexes, belonging to semiurban and rural areas of a mining district of an eastern state of India. Of these patients, 56 belonged to higher per capita income and the remaining 183 to lower per capita income. Their daily intake of food was estimated by questionnaire and weighing food items. It was observed that both the patients $(52 \%)$ as well as normal subjects $(39 \%)$ with low per capita income suffered from grade I and II undernutrition. In contrast (13\%) patients and (14\%) normal subjects with higher per capita income showed only signs of grade I undernutrition. Importantly no patient suffered from severe undernutrition. Furthermore, the intake of protein, fat, calorie and vitamin A was significantly less in the normal as well as patients of low per capita income than that of higher per capita income. It was concluded that moderate undernutrition observed in lepromatous patients was associated with poverty and deprivation of food and not with the disease.
\end{abstract}

\section{Introduction}

Dharmendra ${ }^{1}$ had discussed the various risk factors for the development of lepromatous leprosy in humans and highlighted the possible role of nutritional factors in modulating the immunologic response of the host against Mycobacterium leprae. Earlier, Edelman ${ }^{2}$ mentioned that the interaction between undernutrition and leprosy is potentially complex, poorly documented and barely understood. Although there are a few scattered reports on low serum vitamin A and zinc levels ${ }^{3,4}$ no comprehensive assessment of the nutritional status of the lepromatous patients has been attempted so far. As most of the lepromatous leprosy patients belong to the low socioeconomic groups of society, ${ }^{5}$ one can ask whether nutrition may have a predisposing or aggravating role in the susceptibi- 
lity of these subjects to this disease. Taking all this into account, Dr Stanley Browne at the XII International Leprosy Congress, New Delhi, 1984 asked all leprologists to focus their attention on the interaction of leprosy and malnutrition.

In the present communication, we have reported the results of the assessment of anthropometric measurement and dietary intake of multibacillary lepromatous patients residing in rural and semiurban areas of a copper-mining district.

\section{Subjects and Methods}

\section{STUDY AREA, HUMAN MATERIALS AND DIAGNOSIS OF LEPROMATOUS} LEPROSY

This study was carried out in the Ghatsila copper mines Singhbhum District, a tribal area of Bihar State, Eastern India. Information on population examined and prevalence of leprosy in Singhbhum district study area are given in Figure 1. These data were obtained through house-to-house surveys in collaboration with the medical officer and paramedical workers of Singhbhum Navjivan Niketan, Ghatsila, Bihar, a voluntary organization for leprosy relief. The methodology described by Revankar et al. ${ }^{6}$ was employed.

To determine any association of the economic status of the patients with their illness, the patients were taken from both rural and semiurban areas and divided into two groups: (a) high per capita income group, who were employed as miners and earned their livelihood, and (b) low per capita income group who were unemployed. Their ages ranged from 16 to 65 years. Our control population was comprised of healthy individuals and those who attended the outpatient department of the Hindustan Copper Complex Hospitals, Singhbhum for minor medical ailments, and resided in the same area and were matched for sex and age and belonged to a similar socioeconomic background but had no clinical signs and symptoms of leprosy. The patients with a high income were living with controls of similar income group, while the patients of low income group were living without such controls.

The diagnosis of lepromatous leprosy was established by clinical examination, slit-skin smear and lepromin test. Histological classification was performed according to the method described by Ridley and Jopling. ${ }^{7}$

\section{ANTHROPOMETRIC ASSESSMENT}

Body weight and height were measured by standard techniques. Triceps skinfold thickness was done with Harpenden Calipers. These results were compared with locally prepared standards. ${ }^{8}$ Quetelet index $\left(\mathrm{wt}(\mathrm{g}) / \mathrm{ht}^{2}(\mathrm{~cm})\right)$ was also calculated as an age-independent parameter. 


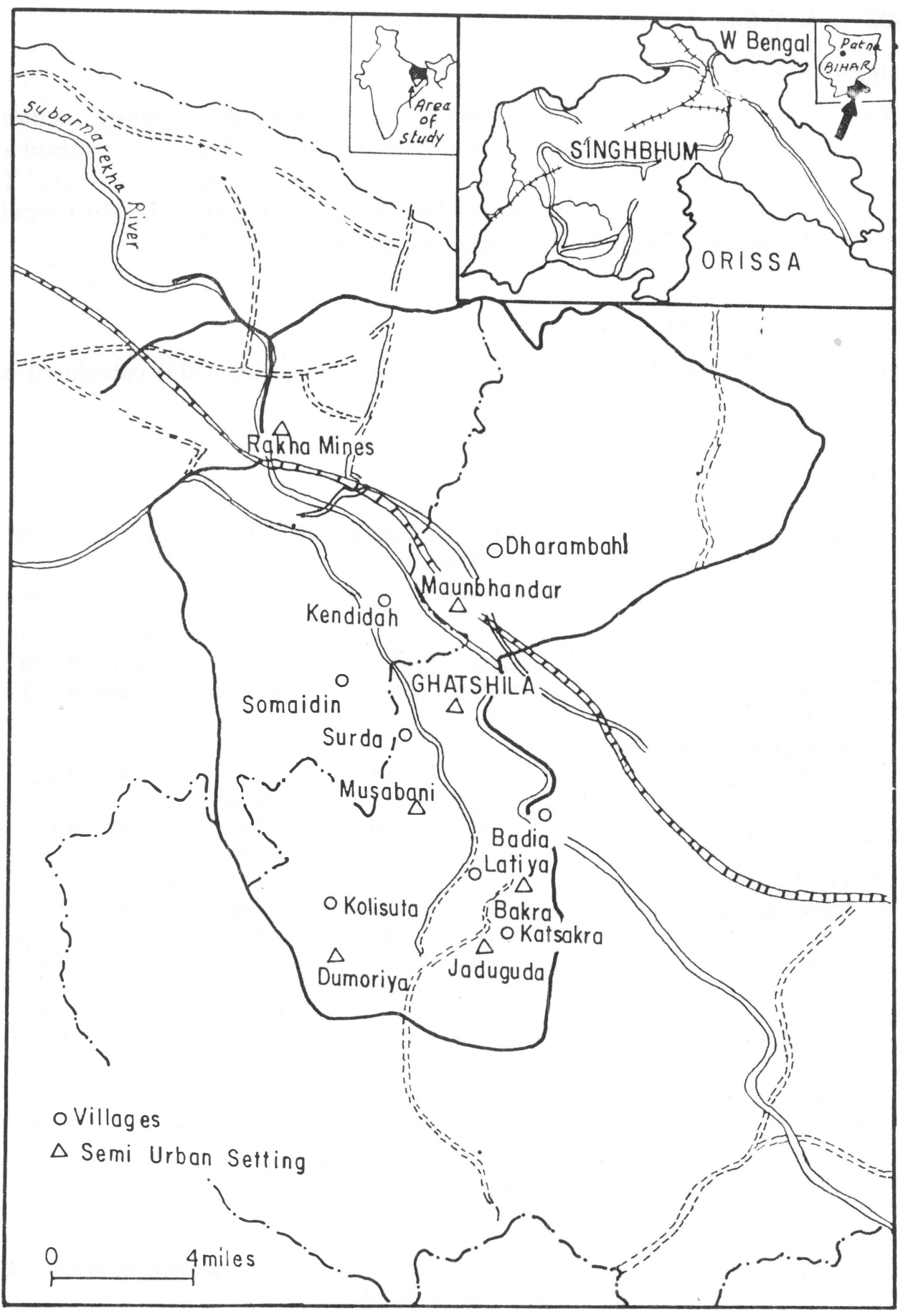

Figure 1. Study area in Singhbhum District, Eastern India. Total area is 13,440 sq. km. Altitude, 92 $\mathrm{m}$ above Mean sea level. Mean rainfall $=1350 \mathrm{~mm} /$ year. Mean Temp: $22.5^{\circ}-45^{\circ} \mathrm{C}$ in summer; $7 \cdot 3-$ $35.6^{\circ} \mathrm{C}$ in winter. Eight villages $(O)$ and 7 semiurban areas $(\Delta)$ were investigated. Amongst the 2704 registered cases, $16 \cdot 16 \%$ (437) were lepromatous, $65 \cdot 6 \%$ (1774) were nonlepromatous and $18 \cdot 23 \%$ (493) were borderline leprosy. Of these total cases, $1 \cdot 6 \%$ (42) were below 14 years of age. 


\section{DIETARY STUDIES}

Data on food intake was collected through a detailed dietary survey, including amounts of food articles consumed by a 24 -hour recall-questionaire method and the actual weighing of food articles cooked daily on two consecutive visits. ${ }^{8}$ The individual food values were then calculated by the method described by Gopalan et al. ${ }^{9}$ for proteins, fats, calories, vitamins and minerals.

\section{STATISTICAL EVALUATION}

The results were grouped, mean and standard deviation (SD) calculated and statistical significant test (student ' $t$ ') was done. ${ }^{10}$

Table 1. Anthropometric measurements of normal and lepromatous male patients in relation to their per capita income (PCI) $(\mathrm{Mean} \pm \mathrm{SD})$

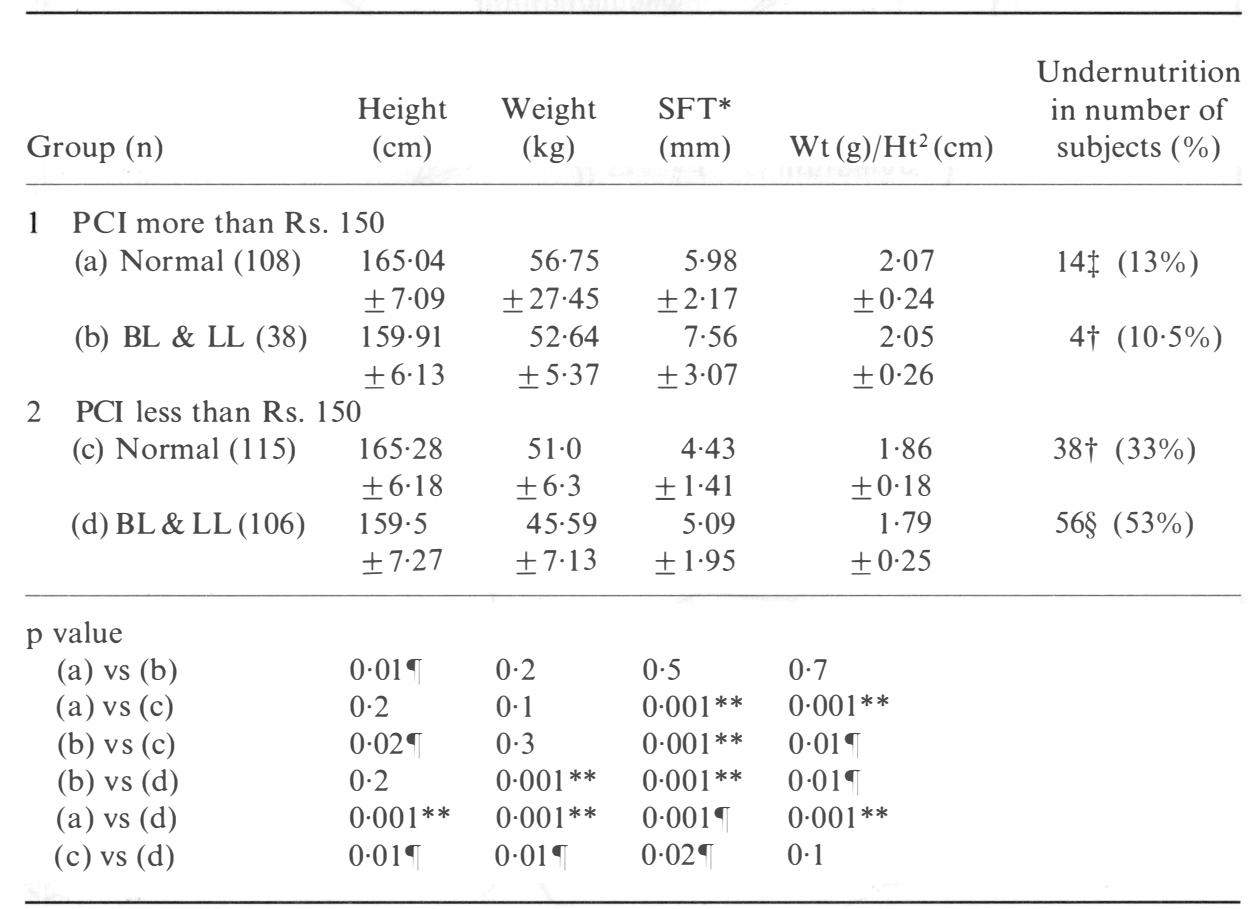

* SFT, Skinfold thickness. (We have taken mean minus 1 SD as grade I; mean minus 2 $\mathrm{SD}$ as grade II; and mean minus $3 \mathrm{SD}$ as grade III undernutrition.)

+ Grade I undernutrition.

$\$ 10$ were of grade I undernutrition and 4 were of grade II undernutrition.

$\S 31$ were grade I and 25 were of grade II undernutrition.

T significant; ** highly significant. 


\section{Results}

Figure 1 illustrates the distribution of the village and semiurban study areas and prevalence of leprosy of Singhbhum District. Although a mining district with natural mineral resources, this is a backward tribal area. Leprosy is hyperendemic with a prevalence rate of 14.6 per thousand population. ${ }^{11}$ Fifty-six lepromatous leprosy patients including their dependents were employed in the mining industry. Their monthly per capita income was more than Rs. 150 . The remaining 183 patients lived in surrounding rural areas, were unemployed and were either begging or doing other manual labour. Their per capita income was less than Rs. 150. In contrast, the miners both healthy subjects and patients with higher per capita income lived in government apartments with separate kitchen and water closets.

Tables 1 and 2 show the anthropometric parameters of the controls and patients of different sexes with respect to their per capita income. These data

Table 2. Anthropometric measurements of normal and lepromatous female patients in relation to their per capita income $(\mathrm{PCI})(\mathrm{Mean} \pm \mathrm{SD})$

\begin{tabular}{|c|c|c|c|c|c|}
\hline Group (n) & $\begin{array}{l}\text { Height } \\
(\mathrm{cm})\end{array}$ & $\begin{array}{l}\text { Weight } \\
(\mathrm{kg})\end{array}$ & $\begin{array}{l}\text { SFT* } \\
(\mathrm{mm})\end{array}$ & $\mathrm{Wt}(\mathrm{g}) / \mathrm{Ht}^{2}(\mathrm{~cm})$ & $\begin{array}{l}\text { Undernutrition } \\
\text { in number of } \\
\text { subjects }(\%)\end{array}$ \\
\hline \multicolumn{6}{|c|}{1 PCI more than Rs. 150} \\
\hline \multirow[t]{2}{*}{ (a) Normal (56) } & $151 \cdot 34$ & $48 \cdot 30$ & $10 \cdot 38$ & $2 \cdot 07$ & $8 \dagger(14 \%)$ \\
\hline & $\pm 4 \cdot 90$ & $\pm 6 \cdot 77$ & $\pm 3 \cdot 44$ & $\pm 0 \cdot 24$ & \\
\hline \multirow[t]{2}{*}{ (b) BL \& LL (18) } & $146 \cdot 89$ & $47 \cdot 35$ & $9 \cdot 36$ & $2 \cdot 20$ & $3 \dagger(16 \%)$ \\
\hline & \pm 5.95 & $\pm 7 \cdot 43$ & $\pm 3 \cdot 45$ & $\pm 0 \cdot 30$ & \\
\hline \multicolumn{6}{|c|}{2 PCI less than Rs. 150} \\
\hline \multirow[t]{2}{*}{ (c) Normal (60) } & $149 \cdot 41$ & $42 \cdot 32$ & $6 \cdot 84$ & $1 \cdot 88$ & $27 \dagger(45 \%)$ \\
\hline & $\pm 4 \cdot 66$ & $\pm 4 \cdot 65$ & $\pm 2 \cdot 33$ & $\pm 0 \cdot 19$ & \\
\hline \multirow[t]{2}{*}{ (d) BL \& LL (77) } & $147 \cdot 75$ & $39 \cdot 08$ & $6 \cdot 89$ & $1 \cdot 82$ & $40 \S(52 \%)$ \\
\hline & $\pm 7 \cdot 34$ & $\pm 6 \cdot 30$ & $\pm 2 \cdot 75$ & $\pm 0 \cdot 23$ & \\
\hline \\
\hline \multicolumn{6}{|l|}{ (a) vs (b) } \\
\hline (a) vs (c) & $0 \cdot 001 * *$ & $0 \cdot 001 * * *$ & $0 \cdot 001 * *$ & $0 \cdot 001^{* *}$ & \\
\hline (b) vs (c) & $0 \cdot 2$ & $0 \cdot 02$ ⿶ & $0 \cdot 05$ & $0 \cdot 001^{* *}$ & \\
\hline (b) vs (d) & $0 \cdot 2$ & $0 \cdot 001^{* *}$ & $0 \cdot 2$ & $0 \cdot 001^{* *}$ & \\
\hline (a) vs (d) & $0 \cdot 001^{* *}$ & $0 \cdot 001^{* *}$ & $0 \cdot 02$ - & $0 \cdot 001^{* *}$ & \\
\hline (c) vs (d) & $0 \cdot 3$ & 0.02 ศ & $0 \cdot 6$ & $0 \cdot 2$ & \\
\hline
\end{tabular}

* SFT, Skinfold thickness. (Grades of undernutrition have been defined in Table 1.)

$\dagger$ Only grade I undernutrition.

$\ddagger 24$ were grade I and 3 were grade II undernutrition.

$\S 28$ were grade I and 12 were grade II undernutrition.

significant; ** highly significant. 
clearly demonstrated that the Quetelet index was significantly less in the control group with low per capita income than those with per capita income more than Rs. 150. Significantly, this index was also low in patients with low per capita income than those with higher per capita income. There was no significant difference in the Quetelet index between the control group with low per capita income and patient group of similar economic status, as well as normal control group with higher per capita income and patients of similar economic class. These results suggested that the undernutrition was associated with poverty and not with leprosy. Some undernourished subjects observed in our patients and controls with a high per capita income were of grade I. However, grade II undernutrition was only observed in patients and controls of low per capita income (Tables 1 and 2). None of our patients had grade III undernutrition.

Tables 3 and 4 show the daily dietary intake of the normal subjects and lepromatous patients (male and female) in relation to their per capita income. It was found that the difference in calorie, protein and carbohydrate intake by the normal subjects with higher per capita income and by those in the lepromatous group with same per capita income was statistically not significant. But

Table 3. Daily dietary intake of male normal and lepromatous subjects in relation to their per capita income $(\mathrm{PCI})(\mathrm{Mean} \pm \mathrm{SD})$

\begin{tabular}{|c|c|c|c|c|c|}
\hline Group & Calories & \multicolumn{3}{|c|}{$\begin{array}{l}\text { Protein Carbohydrate Fat } \\
\text { (g) }\end{array}$} & $\begin{array}{l}\text { Vitamin A } \\
\text { (IU) }\end{array}$ \\
\hline \multicolumn{6}{|c|}{ han Rs. 150} \\
\hline (a) Normal & 2527 & 75 & 465 & 36 & 535 \\
\hline & \pm 298 & +18 & +70 & +7 & \pm 251 \\
\hline (b) BL \& LL & 2539 & 69 & 491 & 31 & 382 \\
\hline & \pm 398 & \pm 14 & \pm 108 & \pm 9 & \pm 237 \\
\hline \multicolumn{6}{|c|}{ n Rs. 150} \\
\hline (c) Normal & 1924 & 44 & 404 & 9 & 248 \\
\hline & \pm 185 & \pm 8 & \pm 56 & \pm 2 & \pm 122 \\
\hline (d) BL \& LL & 1905 & 42 & 374 & 12 & 271 \\
\hline & \pm 273 & \pm 9 & \pm 54 & \pm 4 & \pm 142 \\
\hline \multicolumn{6}{|l|}{$\mathrm{p}$ value } \\
\hline (a) vs (b) & $0 \cdot 3$ & $0 \cdot 2$ & $0 \cdot 3$ & 0.02 - & 0.02 - \\
\hline (a) vs (c) & $0.001 * *$ & $0.001 * *$ & $0 \cdot 001 * *$ & $0.001 * *$ & $0 \cdot 001^{* *}$ \\
\hline (b) vs (c) & $0 \cdot 001^{* *}$ & $0.001 * *$ & $0 \cdot 001 * *$ & $0 \cdot 001 * *$ & 0.01 ศ \\
\hline (b) vs (d) & $0 \cdot 001 * *$ & $0.001 * *$ & $0 \cdot 001 * *$ & $0.001 * *$ & $0.01 \mathrm{~T}$ \\
\hline (a) vs (d) & $0.001 * *$ & $0.001 * *$ & $0.001 * *$ & $0.001 * *$ & $0 \cdot 001 * *$ \\
\hline (c) vs (d) & $0 \cdot 7$ & $0 \cdot 2$ & $0 \cdot 1$ & $0 \cdot 01$ & $0 \cdot 5$ \\
\hline
\end{tabular}

- significant; ${ }^{* *}$ highly significant 
Table 4. Daily dietary intake of female normal and lepromatous subjects in relation to their per capita income $(\mathrm{PCI})(\mathrm{Mean} \pm \mathrm{SD})$

\begin{tabular}{|c|c|c|c|c|c|}
\hline Group & Calories & Protein & $\begin{array}{c}\text { Carbohydrate } \\
\text { (g) }\end{array}$ & Fat & $\begin{array}{l}\text { Vitamin A } \\
\text { (IU) }\end{array}$ \\
\hline \multicolumn{6}{|c|}{1 PCI more than Rs. 150} \\
\hline \multirow[t]{2}{*}{ (a) Normal } & 1897 & 53 & 333 & 34 & 447 \\
\hline & \pm 228 & \pm 18 & \pm 77 & \pm 11 & +203 \\
\hline \multirow[t]{2}{*}{ (b) BL \& LL } & 1880 & 60 & 345 & 28 & 441 \\
\hline & \pm 319 & \pm 18 & \pm 30 & \pm 12 & \pm 156 \\
\hline \multicolumn{6}{|c|}{ PCI less than Rs. 150} \\
\hline \multirow[t]{2}{*}{ (c) Normal } & 1607 & 39 & 332 & 19 & 404 \\
\hline & \pm 91 & \pm 13 & \pm 44 & \pm 17 & \pm 203 \\
\hline \multirow[t]{2}{*}{ (d) BL \& LL } & 1870 & 44 & 392 & 12 & 226 \\
\hline & \pm 384 & \pm 10 & \pm 66 & \pm 4 & \pm 80 \\
\hline \multicolumn{6}{|l|}{$p$ value } \\
\hline (a) vs (b) & $0 \cdot 3$ & $0 \cdot 3$ & $0 \cdot 5$ & $0 \cdot 1$ & $0 \cdot 9$ \\
\hline (a) vs (c) & $0 \cdot 001^{* *}$ & $0 \cdot 2$ & $0 \cdot 2$ & $0 \cdot 001^{* *}$ & $0 \cdot 2$ \\
\hline (b) vs (c) & $0.01^{\top}$ & 0.05 & $0 \cdot 2$ & $0 \cdot 05$ & $0 \cdot 2$ \\
\hline (b) vs (d) & $0 \cdot 4$ & $0 \cdot 1$ & $0 \cdot 2$ & $0 \cdot 001^{* *}$ & $0.001 * *$ \\
\hline (a) vs (d) & $0 \cdot 7$ & $0 \cdot 4$ & $0 \cdot 4$ & $0 \cdot 001 * *$ & $0 \cdot 001 * *$ \\
\hline (c) vs (d) & $0.001 *$ & $0 \cdot 05$ & $0.001 * *$ & 0.01 ศ & $0 \cdot 001^{* *}$ \\
\hline
\end{tabular}

I significant; ${ }^{* *}$ highly significant

paradoxically, the fat and the vitamin A intake by the male patients with PCI more than Rs. 150 was less than their intake by the normal subjects of similar PCI. Similarly, no difference was observed in the calorie, protein and carbohydrate intakes between normal and lepromatous patients with lower PCI. On the contrary significant difference was found in the consumption of these nutrients by normal subjects with higher PCI and those with low PCI. Also, the calorie, protein and carbohydrate intake by the lepromatous group of higher PCI was more than that of leprosy patients of lower PCI. The fat and vitamin A intake by the normal subjects as well as patients with lower PCI was significantly less than the fat and vitamin A intake by subjects with high PCI.

\section{Discussion}

The interaction between nutrition and immunity is complex. Undernutrition leads to impairment of immunity which has a profound impact on the entire immune network. ${ }^{12}$ Assessment of nutritional status requires exact knowledge 
concerning body measurements, nutritional intake, and concurrent illness due to exposure to the environment and the duration of nutritional deprivation.

Defects of the central immune system in the pathogenesis of lepromatous leprosy have recently been illuminated. ${ }^{13}$ Lymphoid organs, both primary as well as secondary, such as thymus, spleen and lymph nodes, are most affected in severe human protein energy deprivation. ${ }^{14}$ Thus, we thought that protein-energy deficiency, so of ten encountered in our population, may lead to impairment of immunity and to the downhill course in the lepromatous pathology. Earlier literature, reviewed by Dharmendra ${ }^{1}$ shows that prevalence of leprosy in the affected parts of the globe could be explained by the deficiency in consumption of salts, fresh vegetables, calcium, thiamin, milk and milk products. As early as 1932, Muir and Santra ${ }^{15}$ reported that the prevalence of leprosy was more in the rice-eating population of India. Later, the association between leprosy and malnutrition was pointed out by Skinsness and Higa ${ }^{16}$. However, Cochrane ${ }^{17}$ did not support these views. Rees ${ }^{18}$ on the other hand stated that the deprivation of nutrition in an individual is a possible risk factor in leprosy, especially in parts of the world where undernutrition is rife. However, there is no conclusive evidence supporting these views. Recently, Sommerfelt et al. ${ }^{19}$ evaluated the possible role of environmental factors, socioeconomic as well as anthropometric parameters in relation to leprosy prevalence in village and field areas in Tamilnadu, India, and observed a higher prevalence of the disease in the villages. McMurray et al. ${ }^{20}$ by animal experiments, have recently shown that in protein deficient guinea-pigs, the reactivity to tuberculin as well as $\mathrm{BCG}$ induced protection against virulent challenges with $M$. tuberculosis $\mathrm{H} 37 \mathrm{RV}$ were diminished.

The present observation revealed that lepromatous patients below poverty* line as well as control subjects of similar economic status suffered from grade I and II undernutrition alike (Tables 1 and 2). As far as we know, this has been the first systematic study describing the association of nutrition and lepromatous leprosy. More importantly the dietary intake by these patients has not been so far documented. Normal subjects without any signs of clinical leprosy but below poverty line, also suffered grade I and II malnutrition (Tables 1 and 2). On the contrary, patients and healthy subjects above the poverty level had showed comparable anthropometric indices. The data on SFT points out that the subcutaneous fat in our female patients with low PCI was not much depleted, showing thereby the undernutrition in them was minimal (Table 2). These findings were further substantiated by the analysis of daily intakes of nutrients (Tables 3-7). In both patients, as well as controls with a low income, daily intake for energy, protein, fat and vitamins seemed to be lower than that consumed by

* Rajalakshmi \& Srikantia ${ }^{21}$ had defined the low economic group with a PCI between 30 and 80 Rs. a month; the national average income of India was 65 Rs. per month. These authors have taken high socioeconomic status with a PCI of more than Rs. 200 per month. On this basis, in this study we have taken the PCI of low economic group to be $150 \mathrm{Rs}$. as the national average income is steadily increasing. 
patients and controls above the poverty line. These findings, therefore, clearly indicated that undernutrition observed in our patients of low income group was poverty associated.

The daily intake of carbohydrate by the normal subjects and patients of both high and low PCI were similar, and seems to be independent of PCI in this 'rice bowl' part of the country. However, the deficiency of calorie intake in low income group (in both patients and controls) seemed to be less for protein and fat consumption, which they cannot afford to purchase. The intake of fresh vegetables and fruits was insufficient. Eggplant, tomatoes, pumpkin and potatoes, cultivated in household surroundings, were the commonly consumed vegetables. Thus, socioeconomic differences observed in our study seems to have an influence on the quality of the nutrient intake. The intake of vitamin A was low in all subjects, which may be accounted for by the pulse-millet based diet (Tables 3 and 4) and low intakes of leafy vegetables and milk (Table 6). A low-income level may thus increase the risk of malnutrition. ${ }^{22}$ In all developing countries, malnutrition is largely the by-product of poverty arising from glaring socioeconomic inequalities.

Table 5. Daily dietary intake (in milligram) of male normal and lepromatous subjects in relation to their per capita income $(\mathrm{PCI})($ Mean $\pm \mathrm{SD})$

\begin{tabular}{|c|c|c|c|c|c|c|}
\hline Group & Thiamine & Riboflavin & Niacin & Vitamin C & Calcium & Iron \\
\hline 1 PCI more the & n Rs. 150 & & & & & \\
\hline (a) Normal & $1 \cdot 39$ & $1 \cdot 06$ & $17 \cdot 23$ & $35 \cdot 82$ & 643 & $29 \cdot 7$ \\
\hline & $\pm 0 \cdot 55$ & $+0 \cdot 41$ & $\pm 4 \cdot 16$ & $\pm 20 \cdot 48$ & \pm 280 & $\pm 9 \cdot 1$ \\
\hline (b) BL \& LL & $1 \cdot 27$ & $0 \cdot 80$ & $16 \cdot 93$ & $26 \cdot 8$ & 322 & $32 \cdot 9$ \\
\hline & $\pm 0 \cdot 60$ & $\pm 0 \cdot 32$ & \pm 3.93 & $\pm 20 \cdot 95$ & \pm 266 & $\pm 12 \cdot 3$ \\
\hline \multicolumn{7}{|c|}{ n Rs. 150} \\
\hline (c) Normal & $0 \cdot 66$ & $0 \cdot 56$ & $11 \cdot 37$ & $28 \cdot 84$ & 132 & $20 \cdot 18$ \\
\hline & $\pm 0 \cdot 18$ & $\pm 0 \cdot 28$ & $\pm 3 \cdot 08$ & $\pm 14 \cdot 6$ & \pm 52 & \pm 6.87 \\
\hline (d) BL \& LL & $0 \cdot 81$ & 0.55 & $11 \cdot 57$ & $27 \cdot 63$ & 164 & $17 \cdot 96$ \\
\hline & $\pm 0 \cdot 34$ & $\pm 0 \cdot 25$ & $\pm 2 \cdot 70$ & \pm 12.78 & \pm 147 & $\pm 6 \cdot 58$ \\
\hline $\begin{array}{l}\text { Recommended } \\
\text { allowance }\end{array}$ & $1 \cdot 4$ & $1 \cdot 5$ & 20 & 50 & 500 & 30 \\
\hline \multicolumn{7}{|l|}{ p Value: } \\
\hline (a) vs (b) & $0 \cdot 9$ & $0.01 \top$ & $0 \cdot 7$ & $0 \cdot 1$ & $0 \cdot 001^{* *}$ & $0 \cdot 9$ \\
\hline (a) vs (c) & $0 \cdot 001^{* *}$ & $0.001 * *$ & $0.001 * *$ & $0 \cdot 1$ & $0 \cdot 001 * *$ & $0.01 \subsetneq$ \\
\hline (b) vs (c) & $0.001 * *$ & $0.001 * *$ & $0.001 * *$ & $0 \cdot 2$ & $0 \cdot 001 * *$ & $0.001 * *$ \\
\hline (b) vs (d) & $0 \cdot 001^{* *}$ & $0.001^{* *}$ & $0.001^{* *}$ & $0 \cdot 2$ & 0.02 - & $0.001^{* *}$ \\
\hline (a) vs (d) & $0.001 * *$ & $0.001 * *$ & $0.001 * *$ & $0 \cdot 2$ & $0 \cdot 001 * *$ & $0.001 * *$ \\
\hline (c) vs (d) & $0 \cdot 7$ & $0 \cdot 7$ & $0 \cdot 7$ & $0 \cdot 6$ & $0 \cdot 1$ & $0 \cdot 1$ \\
\hline
\end{tabular}

T significant; ** highly significant 
Table 6. Daily dietary intake (milligram) of female normal and lepromatous subjects in relation to their per capita income $(\mathrm{PCI})(\mathrm{Mean} \pm \mathrm{SD})$

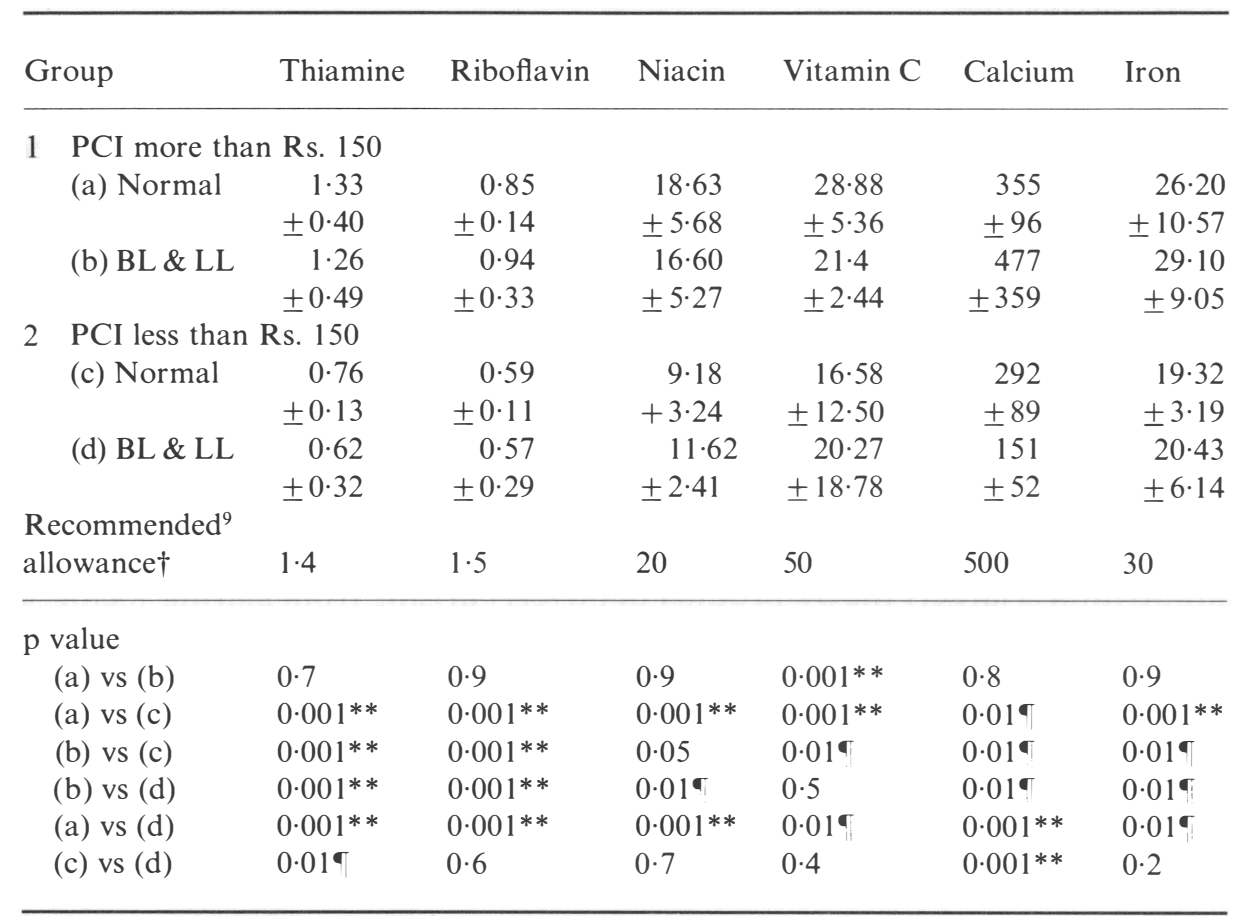

- Significant $* *$ Highly significant

Table 7. Daily intake of dietary items of healthy controls and lepromatous patients $(\mathrm{g})$ $(\mathrm{Mean} \pm \mathrm{SD})$ with respect to their per capita income (PCI)

\begin{tabular}{|c|c|c|c|c|c|}
\hline \multirow[b]{2}{*}{$\begin{array}{l}\text { Dietary } \\
\text { item }\end{array}$} & \multicolumn{2}{|c|}{ Normals with PCI } & \multicolumn{2}{|c|}{$\begin{array}{c}\text { Lepromatous with } \\
\text { PCI }\end{array}$} & \multirow{2}{*}{$\begin{array}{c}\text { Recommendec } \\
\text { dietary } \\
\text { allowance }{ }^{9}\end{array}$} \\
\hline & $\begin{array}{l}\text { More than } \\
\text { Rs. } 150\end{array}$ & $\begin{array}{l}\text { Less than } \\
\text { Rs. } 150\end{array}$ & $\begin{array}{l}\text { More than } \\
\text { Rs. } 150\end{array}$ & $\begin{array}{l}\text { Less than } \\
\text { Rs. } 150\end{array}$ & \\
\hline Cereals & $385 \pm 74$ & $364 \pm 49$ & $394 \pm 69$ & $376 \pm 52$ & 370 \\
\hline Pulses & $62 \pm 14$ & $41 \pm 16$ & $64 \pm 19$ & $43 \pm 11$ & 75 \\
\hline Fats & $36 \pm 18$ & $15 \pm 6$ & $29 \pm 11$ & $12 \pm 3$ & 57 \\
\hline Tuberous roots & $60 \pm 20$ & $40 \pm 15$ & $65 \pm 35$ & $36 \pm 12$ & 85 \\
\hline Leafy vegetables & $35 \pm 6$ & $9 \pm 4$ & $22 \pm 7$ & $6 \pm 3$ & 114 \\
\hline Vegetables & $85 \pm 32$ & $62 \pm 18$ & $78 \pm 38$ & $53 \pm 34$ & 85 \\
\hline Fruits & $40 \pm 16$ & $15 \pm 6$ & $35 \pm 17$ & $8 \pm 5$ & 38 \\
\hline Milk and products & $390 \pm 60$ & $96 \pm 34$ & $365 \pm 98$ & $38 \pm 16$ & 285 \\
\hline Sugar & $25 \pm 6$ & $15+8$ & $21 \pm 16$ & $8 \pm 6$ & 57 \\
\hline Meat and fish & $65 \pm 30$ & $15 \pm 12$ & $48 \pm 32$ & $13 \pm 7$ & 86 \\
\hline
\end{tabular}




\section{Acknowledgments}

The authors are grateful to $\mathrm{P}$ Hemchandran and K Nambiar of Singhbhum Navjivan Niketan, Ghatsila, Bihar and Senior Manager (Medical), Hindustan Copper Complex Hospitals, Ghatsila, Bihar. Partial financial assistance from the Indian Council of Medical Research, New Delhi is gratefully acknowledged.

\section{References}

1 Dharmendra. Susceptibility of the host. Role of non genetic factors. Lepr India, 1982; 54: 721-52.

2 Edelman R. Malnutrition and leprosy. An analytical review. Lepr India, 1979; 51: 376-88.

${ }^{3}$ Sher R, Schulman G, Baily P, Politzer W. Serum trace elements and vitamin A in leprosy subtypes. Amer J Clin Nutr, 1981; 34: 1918-24.

${ }^{4}$ Venkatesan K, Kannan KB, Bharadwaj VP, Sritharam V, Katoch K, Usha R, Ramu G. Serum Copper and zinc in leprosy and its effect on oral zinc therapy. Indian J Med Res, 1983; 78: 3741.

${ }^{5}$ Ojha KS, Chaudhary RC, Chaudhary SK. Socio-environmental factors in relation to leprosy at Jaipur. Indian J Lepr, 1984; 56: 884-88.

${ }^{6}$ Revankar CR, Dudhalkar B, Raju GD, Ganapati R. Leprosy surveys in urban slumspossibilities for epidemiological investigations. Lepr Rev, 1982; 53: 99-104.

7 Ridley DS, Jopling WH. Classification of leprosy according to immunity. A five group system. Int J Lepr, 1966; 34: 255-73.

8 Jeliffe DB. The assessment of nutritional status of the community. WHO Monograph. Ser. No. $53,1966$.

9 Gopalan C, Ramasastri BV, Balasubrahmaniam SC. Nutritive Value of Indian Foods. National Institute of Nutrition, Indian Council of Medical Research, Hyderabad, India, 1981.

10 Mahajan BK. Methods in Biostatistics, 4th ed. Smt. Indu Mahajan, Leipzig Press, New Delhi, 1984.

11 Das KC. Leprosy control in India. Bull National Lepr Orgn, 1984; 13: 19-27.

12 Chandra RK. Immunocompetence as a functional index of nutritional status. Brit Med Bull, 1981; 37: 89-94.

${ }^{13}$ Godal T. Leprosy immunology. Some aspects of the role of the immune system in the pathogenesis of the disease. Lepr Rev, 1984; 55: 407-14.

14 Rundles SC. Effects of nutritional status on immunological function. Amer J Clin Nutr, 1982; 35: 1202-10.

${ }_{15}$ Muir E, Santra I. Sample Surveys of leprosy in India. Indian J Med Res, 1932; 20: 421-34.

16 Skinsness OK, Higa $\mathrm{H}$. The role of protein malnutrition in the pathogenesis of ulcerative lazarine leprosy. Int J Leprosy, 1976; 44: 346-58.

17 Cochrane RC, Davey TF. Leprosy in theory and practice, Bristol, 1964. John Wright and Sons Ltd.

18 Rees RJW. Non specific factors that influence susceptibility to leprosy. Lepr Rev, 1981; 52: 13746.

19 Sommerfelt H, Irgens LM, Christian M. Variation in the occurrence of leprosy within small geographic area. Some epidemiological clues. Abstract No. 351/A. XII International leprosy congress, New Delhi, India. Feb. 20-25, 1984.

20 McMurray DN, Mintzer CL, Tetzlaff CL, Carlmagno MH. The influence of dietary protein on the protective effect of BCG in guinea pigs. Tubercle, 1986; 67: 31-39.

${ }^{21}$ Rajalakshmi K, Srikantia SG. Copper, zinc and magnesium content of breast milk of Indian women. Amer J Clin Nutr, 1980; 33: 664-69.

${ }^{22}$ Owen GM, Kram KM, Garry PJ, Lowe JE, Rubin AH. A study of nutritional status of preschool children in the United States. Paed, 1974; 53: 597-646. 